\title{
HYPERLEDGER FRAMEWORKS WITH A SPECIAL FOCUS ON HYPERLEDGER FABRIC
}

\author{
Marija S. Krstića , Lazar J. Krstić ${ }^{b}$ \\ Academy of Vocational Studies Southern Serbia, \\ Department of Business Studies, Leskovac, Republic of Serbia \\ a e-mail: krstic.marija@vpsle.edu.rs, corresponding author, \\ ORCID iD: (i)https://orcid.org/0000-0003-3009-8400 \\ be-mail: krstic.lazar@vpsle.edu.rs, \\ ORCID iD: Dhttps://orcid.org/0000-0001-9131-6876
}

DOI: 10.5937/vojtehg68-26206; https://doi.org/10.5937/vojtehg68-26206

FIELD: IT

ARTICLE TYPE: Professional Paper

\begin{abstract}
:
Introduction/purpose: The Blockchain market is a developing market, and many industries are increasingly aware of the importance of having and implementing Blockchain due to changing business conditions. After an introductory consideration of the Blockchain concept, the article focuses on the projects under the Linux Hyperledger Initiative, with particular reference to Hyperledger Fabric, notably on the concepts, architecture, organizational focus, private channels and smart contracts, as well as flow of transactions in the Hyperledger Fabric network. In the last, practical part of the paper, we presented a simulation of a business network and created a simple application for money exchange using the Hyperledger Fabric framework. The aim of the paper is to present the Hyperledger frameworks and highlight all the details of Hyperledger Fabric in order to determine whether its application in practice is justified.
\end{abstract}

Methods: Basic methods (analysis, synthesis, deduction, induction, concretization, generalization) as well as general-scientific methods (analytical-deductive and comparative) were used.

Results: All relevant features of Hyperledger Fabric were considered, a blockchain business network based on it was built, and an application for cash exchange through the network was created.

Conclusion: Hyperledger Fabric is the most comprehensive and the most flexible Hyperledger framework with the largest number of use cases.

Key words: Blockchain, Hyperledger, Hyperledger Fabric. 


\section{Introduction}

Blockchain technology is considered a suitable catalyst for transformation and has the potential to become a digital trend in the near future. This modern technology provides data duplication on all devices participating in the network. Blockchain is suitable for end users because the data cannot be changed after storage in a chain of blocks. Namely, each data update is correctly recorded, which facilitates the process of recording transactions and tracking assets in the business network.

Using open source tools, we strive to create Blockchain techniques available to a wide range of people. One such tool is Hyperledger, a set of technologies used to create new blockchains. The application of Hyperledger Blockchain technologies in business processes improves transparency, enhances accountability and algorithmically guarantees trust between business partners. The technologies created within the Hyperledger projects are increasingly called Third Generation Blockchain systems, where the first generation is considered to be Bitcoin, and the second Ethereum.

The paper presents research on the topic of Hyperledger projects with special reference to Hyperledger Fabric. The first part is an introduction to the basic concepts and principles of Blockchain technology, which enables a decentralized way of data storage. After giving the basics of the Blockchain technology, the research continues in the direction of the Hyperledger initiative of the Linux Foundation in the second part of the paper. The third part is dedicated to Hyperledger Fabric, i.e. concepts, architecture, organizational focus, private channels, smart contracts and transactions in the Hyperledger Fabric network. In the last, practical part of the paper, a simulation of a business network is given and a simple application for money exchange is created, with the aim of a simpler understanding of the Hyperledger Fabric working principle.

\section{Blockchain technology}

Blockchain technology is a distributed replicated database. It is organized in the form of a single-linked list (chain), where nodes are blocks with data on transactions, protected by cryptographic methods after grouping. Hence the name Blockchain. It is a system that enables the realization of digital transactions without intermediaries. It is based on the P2P architecture, where the nodes that participate in the implementation of the service have a copy of all records, and constantly communicate with each other and synchronize records (Minović, 2017). 
To support consistent updating of information and to enable a full range of functions in the general ledger (transactions, queries, etc.), the Blockchain network uses smart contracts to provide controlled access to the ledger. Smart contracts are not only a key mechanism for encapsulating information and maintaining online simplicity, but can also be drawn up to allow participants to automatically execute certain aspects of transactions. The process by which general ledger transactions are synchronized online, to ensure that the general ledger is updated only when the transactions are approved by the respective participants and that the transactions remain in the same order when updating the general ledger, is called consensus.

The consensus mechanism can be said to represent a predefined cryptographic validation method that ensures the correct sequencing of transactions on Blockchain. The consensus algorithm defines the rules, i.e. the ways in which network participants can reach an agreement on transaction validation. The most commonly used algorithms are Proof of Work (PoW) and Proof of Stake (PoS).

Proof of Work is the most widespread way of reaching consensus, which is based on mining. To validate a transaction, each node must perform a complex mathematical calculation. That is why the device consumes certain resources: electricity and processing power. On the other hand, for successful validation, a node (miner) is rewarded with a certain monetary value in cryptocurrency. The more processing power it has, the faster the node will complete the mathematical calculation and get the reward, that is, will earn more. Proof of Stake does not involve mining, some nodes validate transactions and others confirm them, and everyone keeps part of their money in a virtual safe and whoever tries to cheat the system loses money (Pavlović, 2018).

Blockchain can be classified into three types: public, private and allowed Blockchain. The classification is based on the node's ability to access or add a new block to the network. Public blockchain networks are widely available, any node can join the network, participate in transactions and create blocks. The examples of public blockchain are Bitcoin, Ethereum, Dash and Litecoin. On the other hand, with private Blockchain networks, only invited members are allowed to join the network and there is no anonymity of participants, as with public networks. The identity of each participant is known and cryptographically authenticated, on the basis of which the execution of transactions is monitored. Access rights to executed transactions may be granted to anyone or restricted in some way. The examples of private Blockchain 
are Hydrachain Ripple, Monaco and Multichain. The third type of Blockchain, which is the middle ground between private and public Blockchain, is known as a consortium or allowed Blockchain. In this type of blockchain, the network is controlled by a group of nodes. The examples of the consortium Blockchain network are Hyperledger Fabric and Corda (Nasir et al, 2018).

Blockchain can also be said to be a collaborative data registry. Each time the data is accessed and modified, the change is recorded and confirmed, followed by encryption that cannot be subsequently edited. All changes are saved and added to the total record, and each subsequent change requires a repetition of the entire process, with the data being stored in a new block that is encrypted and attached to the previous block. Blockchain requires a lot of processing power due to the complex cryptography that computers have to solve in order to enable storage and access to data. Six basic qualities of Blockchain can be singled out, which together form a functional system (Piljan et al, 2018):

- Decentralization: Blockchain is a distributed database located on all users' computers around the planet, i.e. on the Internet. Thus, there is no central database that can be attacked, hacked or forged. Also, there is no need for an intermediary - information, money, securities or something else can be sent without the need for a broker or a third party (PayPal, Western Union).

- Encryption: Blockchain is encrypted, it uses an advanced encryption technique using private and public keys providing virtually complete security in the authenticity of the transmitted data.

- Transparency: Blockchain is public. All users have access to the database and no one can hide an individual transaction.

- Inclusiveness: Blockchain does not require special technical preconditions for participation, the protocol is designed in such a way that it can be implemented on practically any computer or mobile device, thus providing the possibility of use to practically the entire Internet population.

- Immutability: after a transaction has been executed, verified and placed in a block, it is linked to the previous transaction or block. This structure is marked with a unique code and timestamp, which prevents the possibility of subsequent changes.

- Historicity: there is no way to steal a transaction or data about a block, because that would mean rewriting the entire Blockchain, or all transactions ever performed in it. This means that Blockchain at all times contains all transactions that have been executed since the chain was created. 


\section{Hyperledger}

Hyperledger is an open source project founded by the Linux Foundation. The initiative was launched in December 2015 in order to advance and promote Blockchain technologies and expand the possibilities of their application in the business world. Members of the Hyperledger initiative are many of the world's leading companies in the fields of information and high technologies, finance and banking, production and distribution of products (supply chain), such as: Intel, IBM, Cisco, Airbus, Daimler, JP Morgan, American Express, Deloitte, PWC, BNP Paribas, Baidu, SAP, Huawei, as well as many others, including the domestic company GameCredits (Gajić, 2018).

Hyperledger is not a unique Blockchain technology, but a collection of technologies included by member companies. Although there is a long-term goal of greater integration between projects, most Hyperledger projects still operate independently. Hyperledger has never issued its cryptocurrency, and according to its founders, it will continue to do so in the future. Concrete technologies can be said to be explicitly designed and built for enterprise use cases, not for public markets.

The active development of Hyperledger projects took place at the beginning of 2016, and it implies the development of a larger number of frameworks and tools. Hyperledger frameworks, i.e. distributed ledger technology (DLT) technologies include Fabric, Sawtooth, Iroha, Indy and Burrow, while tools are being developed from Composer, Cello and Explorer (Dhillon et al, 2017).

Each of the Hyperledger technologies has its own specific advantages in certain applications. Some of the mentioned technologies have advanced in the development phases and are actively applied (Fabric, Sawtooth, Iroha), while others are still in the incubation phase (Burrow, Indy). As far as tools are concerned, the most developed is Composer.

Hyperledger projects follow a design philosophy that includes a modular extensible approach, interoperability, an emphasis on highly secure solutions, a token-based approach without a native cryptocurrency, and the development of a rich and simple application user interface. The modular approach allows developers to experiment with creating different types of components. They can create components that can be combined, in order to develop distributed general ledger solutions that meet different requirements. Hyperledger recognizes that security is a fundamental aspect of distributed general ledgers, as many 
use cases involve large-value transactions or sensitive data. In the future, many different Blockchain networks will have to communicate and exchange data in order to form more complex and powerful networks. A high degree of interoperability will provide support for a growing application of Blockchain. Also, Hyperledger projects provide rich and simple application user interfaces that support interoperability with other systems. However, the design philosophy includes the ability to create tokens used to manage digital objects which can represent currencies.

The Hyperledger Architecture Working Group has singled out the following business components of Blockchain (Hyperledger, 2018):

- Consensus Layer - Responsible for creating an order agreement and validating the set of transactions that make up the block.

- Smart Contract Layer - Responsible for processing transaction requests and determining the validity of transactions by applying business logic.

- Communication layer - Responsible for peer-to-peer transmission of messages between nodes participating in a common general ledger.

- Data Warehouse Abstraction - Allows different data warehouses to be used in other modules.

- Crypto Abstraction - Allows you to replace different crypto algorithms or modules without affecting other modules.

- Identity Services - Allows you to establish trust roots during Blockchain instance setup, enroll and register identities or system entities during network operation, and manage changes. They also provide authentication and authorization.

- Access Services - Responsible for managing various approaches specified in the system, such as the validation approach, the consensus approach, or the group management approach. They connect and depend on other modules to implement different approaches.

- Application User Interfaces - Allows clients and applications to connect to Blockchain.

- Interoperability - Interoperability between different Blockchains is supported.

\section{Hyperledger goals}

Hyperledger provides a neutral space for software collaboration between companies that are traditionally competitors. It also provides a neutral space for cross-sectoral cooperation. Blockchains in Hyperledger are allowed and are specifically designed to be business solutions. Because it is a system that requires permission, only those authorized can join the network. This makes it more secure, as the administrator can 
restrict access to Blockchain. In addition, instead of making all transactions available to everyone online, they are only shown to the relevant parties. Hyperledger's goals include (Hyperledger, 2020d):

- Creating acceptable working environments, i.e. distributed open source ledger technologies as well as code bases to support business transactions.

- Providing a neutral, open community-based infrastructure supported by business and technical management.

- Creating technical communities to develop Blockchain and use cases.

- Educating the public about market opportunities for Blockchain technology.

- Promoting the community using access to tools with many platforms and frameworks.

\section{Hyperledger frameworks}

Each of the Hyperledger technologies of the distributed general ledger has its own specific advantages in certain applications. The Hyperledger frameworks are used to build business blockchains for a consortium of organizations. Hyperledger incubates and promotes a range of business blockchain technologies, including (Blockstuffs, 2018):

- distributed general ledger frameworks,

- smart contracts,

- graphical interfaces,

- library client,

- service libraries, and

- simple applications.

The Hyperledger strategy encourages the reuse of common blocks, enables rapid component innovation, and promotes interoperability between projects. As already mentioned, five Hyperledger Blockchain frameworks can be singled out (Suprunov, 2018):

- Hyperledger Fabric,

- Hyperledger Iroha,

- Hyperledger Indy,

- Hyperledger Sawtooth, and

- Hyperledger Burrow.

Hyperledger Fabric is the basis for developing applications or solutions with a modular architecture. It allows components, such as 
consensus and Membership Services Providers (MSP), to be plug-andplay.

Iroha Hyperledger is designed to be simple and easy to engage in infrastructure projects that require distributed general ledger technology. Hyperledger Iroha has a simple construction, modern $\mathrm{C}++$ domain-based design, and it emphasizes the development of mobile applications, as well as a new, chain-based, Byzantine Fault Tolerance consensus algorithm, called Sumeragi (IBM Global Business Services, 2019).

Hyperledger Indy is a distributed general ledger, built for a decentralized identity. Indy provides tools, libraries, and components that can be reused to create and use independent digital identities based on Blockchain or other distributed general ledgers. These identities are interoperable across administrative domains, applications, and all other parts of organizations. The key characteristics of Indy are (Blockstuffs, 2018):

- Independence - Indy keeps identity artifacts in the general ledger with distributed ownership. These artifacts can include public keys and evidence of existence, and no one but the rightful owner can change or remove the identity.

- Privacy - Indy maintains privacy by default, as any identity owner can operate without any risk of correlation or trace.

- Verifiable requirements - Identification requirements may resemble known credentials such as birth certificates, driver's licenses, passports, etc. They can be combined and transformed using methods that reveal only certain information to allow selective disclosure of only the data needed in a particular context.

Hyperledger Sawtooth is a modular platform for building, implementing, and managing distributed general ledgers. Distributed general ledgers provide a digital record (such as property ownership) that is maintained without central management or implementation. In addition to enabling organizations to organize, build, implement, and run complex distributed books, this platform includes a new consensus algorithm, Proof of Elapsed Time (PoET), that targets large distributed populations of validators with minimal resource consumption (Hyperledger, 2020b). Sawtooth contains several technical innovations, such as dynamic consensus, proof of elapsed time, compatibility with Ethereum contracts, parallel transaction execution, and private transactions. Dynamic consensus allows a consortium to change consensus algorithms on a running blockchain by simply starting a transaction. Proof of Elapsed Time is a consensus algorithm with proven usability in operation, but 
without high energy consumption. Smart contract abstraction is also enabled, allowing users to create smart contracts in the language of their choice. In terms of private transactions, Sawtooth node clusters can be easily used with separate permissions, ensuring privacy and confidentiality among participants in that particular chain.

Hyperledger Burrow is a modular Blockchain client with a permitted smart contract interpreter that is partially done in the Ethereum Virtual Machine (EVM) specification (Hyperledger, 2020a). It can be said that Burrow is a smart contract machine that requires a license. Monax originally developed and proposed this machine to Hyperledger. Burrow provides an extremely deterministic, smart blockchain design that focuses on contracts. The components that Burrow encompasses are the consensus mechanism, the Application Blockchain Interface $(\mathrm{ABCl})$, the smart contract mechanism, and the gateway. The consensus mechanism maintains a network stack between nodes and ordered transactions that will be used by applications. The $\mathrm{ABCl}$ application interface provides an interface specification for connecting the consensus mechanism and the application. The smart contract mechanism provides developers with an extremely deterministic mechanism for managing complex industrial processes. The gateway provides a programming interface for system integrations and user interfaces.

\section{Hyperledger tools}

Tools, such as software that facilitate deployment, debugging, and design, can make a huge difference in the ease of use of any system, for both developers and users. Hyperledger is constantly investing in building great support tools. There are several tools that allow easy and efficient access to Blockchain. The most used among the tools are Hyperledger Composer, Hyperledger Cello, Hyperledger Explorer and Hyperledger Caliper.

Hyperledger Composer is the most developed and most powerful Hyperledger tool. It can be said that it is a framework for Hyperledger Fabric. Using Composer brings simpler concepts for Hyperledger Fabric, called Business Network Definitions (BND). These are source code packages that define a business network. This includes permissions, queries, participants, assets and transaction definitions, as well as the implementation of different types of transactions. GNI should be applied to all nodes of the Hyperledger Fabric network. Hyperledger Fabric is implemented with Hyperledger Composer as a platform and infrastructure (Verhoelen, 2018). Hyperledger Composer is written in 
JavaScript and is the most active tool for development activity. It is a tool for building business blockchain networks, and is designed to accelerate the integration of block applications and smart contracts with existing business models. This tool is a framework that accelerates the development of applications developed through Hyperledger Fabric.

Hyperledger Cello enables easy hosting of Blockchain, connected components and infrastructure according to external sites. It is a modulebased Blockchain tool and a service system. Also called Blockchain as a Service (BaaS), it allows the user to maintain a Blockchain network and infrastructure (Blockstuffs, 2018). BaaS is an offer that allows users to leverage cloud-based solutions to build, host and use their Blockchain applications, smart contracts and Blockchain-based features, while a cloud-based service provider manages all necessary infrastructure maintenance tasks and activities. Hyperledger Cello also provides tracking and analytics capabilities.

Hyperledger Explorer provides a control panel for viewing block information, node logs, statistics, smart contracts, transactions, and all other information stored in Blockchain. Users can query for specific blocks or transactions to see complete details. Hyperledger Explorer can integrate with any authentication or authorization platform, commercial or open source, to provide features that match user privileges.

Hyperledger Caliper allows users to measure the performance of a particular Blockchain implementation with a set of predefined use cases. Hyperledger Caliper allows you to create reports that contain a number of performance indicators, such as Transactions Per Second, Transaction delays, and resource usage (Kuhrt, 2019). Hyperledger Caliper is a performance testing tool for Hyperledger blockchain solutions such as Fabric, Composer, Iroha, and others. Using Caliper, the team working on Blockchain applications can take continuous measurements while building smart contracts and transaction logic and use those measurements to track performance changes. Caliper is compatible with Sawtooth, Indi and Fabric Blockchain systems.

\section{Hyperledger Fabric}

Hyperledger Fabric, as a Hyperledger framework, is the most advanced in development. It is interesting to note that, as part of the Hyperledger project, it originated from IBM. This work environment offers a modular architecture in which components such as consensus algorithms and membership service providers can be modified on a plugand-play basis. 
Hyperledger Fabric is a platform for software solutions that use a distributed general ledger (database). It is a private, permissive blockchain infrastructure that provides a modular architecture with delineating roles between nodes within the Blockchain system, executing smart contracts, and configurable consensus and membership services. Its advantages are: identity management, channel privacy and confidentiality, efficient data transmission processing, chaincode functionality, and modular design.

Hyperledger Fabric is designed to be a company-oriented Blockchain solution that is extremely modular and adaptable. Hyperledger Fabric is private and requires permission. This means that it is understood that Hyperledger Blockchains are not available to the general public and do not have tokens that can be exchanged. Blockchain users must have verified identities and join Blockchain using a Membership Service Provider (MSP). Membership service providers are configured in the system, and there may be more than one, but all members must be accessible by one or more membership service providers. Hyperledger Fabric also has a number of special tools that make it particularly well equipped (Hill et al, 2018).

Hyperledger Fabric technology distributed general ledgers profit from the advantages of container technologies for working with smart contracts, which in this context are called a program code chain and which realize the application logic of the system using the Go programming language. The specific mechanism of private channels that exists in Hyperledger Fabric allows the sharing of confidential information between individual participants in the Blockchain network. The key features that set Hyperledger Fabric apart as a comprehensive and customizable Blockchain solution are (Hyperledger-fabricdocs Documentation, 2019):

- Assets - Definitions of assets allow the exchange of almost anything that has monetary value over the network, from food through old cars to the currencies of the future.

- Chaincode - Chaincode execution is separate from transaction handling, limiting required levels of trust and verification across nodes, and optimizing network scalability and performance.

- General Ledger Features - A fixed, shared book that encodes the entire transaction history for each channel and includes the ability to ask SQL like queries for more efficient audit and dispute resolution.

- Channel privacy - Channels enable multilateral transactions with a high degree of privacy and confidentiality required by competing 
companies and industries that exchange assets through a common network.

- Security and Services for Members - Membership that requires permission provides a reliable Blockchain network, where participants know that all transactions can be detected and monitored by authorized regulators and auditors.

- Consensus - A unique approach to consensus provides the flexibility and usability that a company needs.

Another important feature introduced by Hyperledger Fabric is confidentiality when performing transactions on the same network of nodes. Hyperledger Fabric adopts the following terminology related to its workflow: Blockchain "application" through the interface manages the user and the network. Smart contracts are also called chain codes and are provided using the Node SDK, Java SDK and command line interface - as development tools (Belotti et al, 2019).

\section{Features of architecture}

Hyperledger Fabric is designed with several key features and use cases that are considered important for business users. It is basically a general ledger. The general ledger is a set of blocks, and each block contains a set of transactions. A transaction is anything that changes/updates the state of a Blockchain. Transactions, in turn, are performed using smart contract codes installed on Blockchain. The general ledger records the status of data and transactions, and each node in the network has a replicated copy of the general ledger. There are two basic components to a general ledger:

- World state database in which the current values of general ledger data are recorded. It provides fast and efficient access to current values, instead of searching transaction logs. Data is stored by key-value structure, and this database is characterized by frequent additions, updates and deletions.

- A transaction log that records all changes over the world state database, and once recorded, data cannot be changed or deleted.

The blocks are arranged sequentially, and within each block there is a set of transactions. These transactions are also stored as events in a specific sequence. Unlike other Blockchains, the creation of a transaction and the resulting string does not necessarily occur at the same time or on the same computer. This is because ordering transactions is separate from executing transactions. In Hyperledger Fabric, computers used to 
manage Blockchain can be included in three different ways (node types), and these are (Hill et al, 2018):

- Client: The client acts on behalf of the Blockchain user and submits actions and events to the network as part of the application.

- Peers: Peers process incoming validation transactions and update status changes as a result of transactions and chain code applications. When they make a transaction, they broadcast the result to the network so that the transaction can be done by the customer.

- Client: While the peer nodes execute transactions, the client nodes review all executed transactions and decide on the final order that is considered to have occurred in the Blockchain. The nodes that ordered the service decide on the final sequence of events and thus decide on the final set of events to be printed on the next block of the Blockchain.

There is a possibility that one computer performs the function of all three types of nodes on the Hyperledger Fabric Blockchain. While it is possible for the same computer on the Hyperledger network to execute transactions and determine their sequence, Hyperledger is able to evolve even further by providing them as separate services.

Figure 1 shows how applications communicate with peers to access the general ledger. The general ledger query involves a simple three-step dialogue between the application and the node, while updating the general ledger is a little more complicated and includes two additional steps. Applications connect to nodes whenever they need access to general ledgers and chain codes. Nodes, in collaboration with customers, ensure that the general ledger updates changes to all nodes in the network.

In a specific example (Figure 1), the application A connects to the node $\mathrm{P} 1$ and calls the chain $\mathrm{S} 1$ to query or update the general ledger $\mathrm{L} 1$. $\mathrm{P} 1$ invites $\mathrm{S} 1$ to generate a response to a proposal that contains the result of a query or a proposed general ledger update. The application $A$ receives a response to a proposal and the query process ends. For updates, the application A builds a transaction from all responses, which it sends to the client 01 . It collects transactions over the network in blocks and distributes them to all nodes, including P1. P1 confirms the transaction before it is applied to L1. When L1 is updated, P1 generates an event, received by A, to indicate completion (Hyperledger, 2020c). 


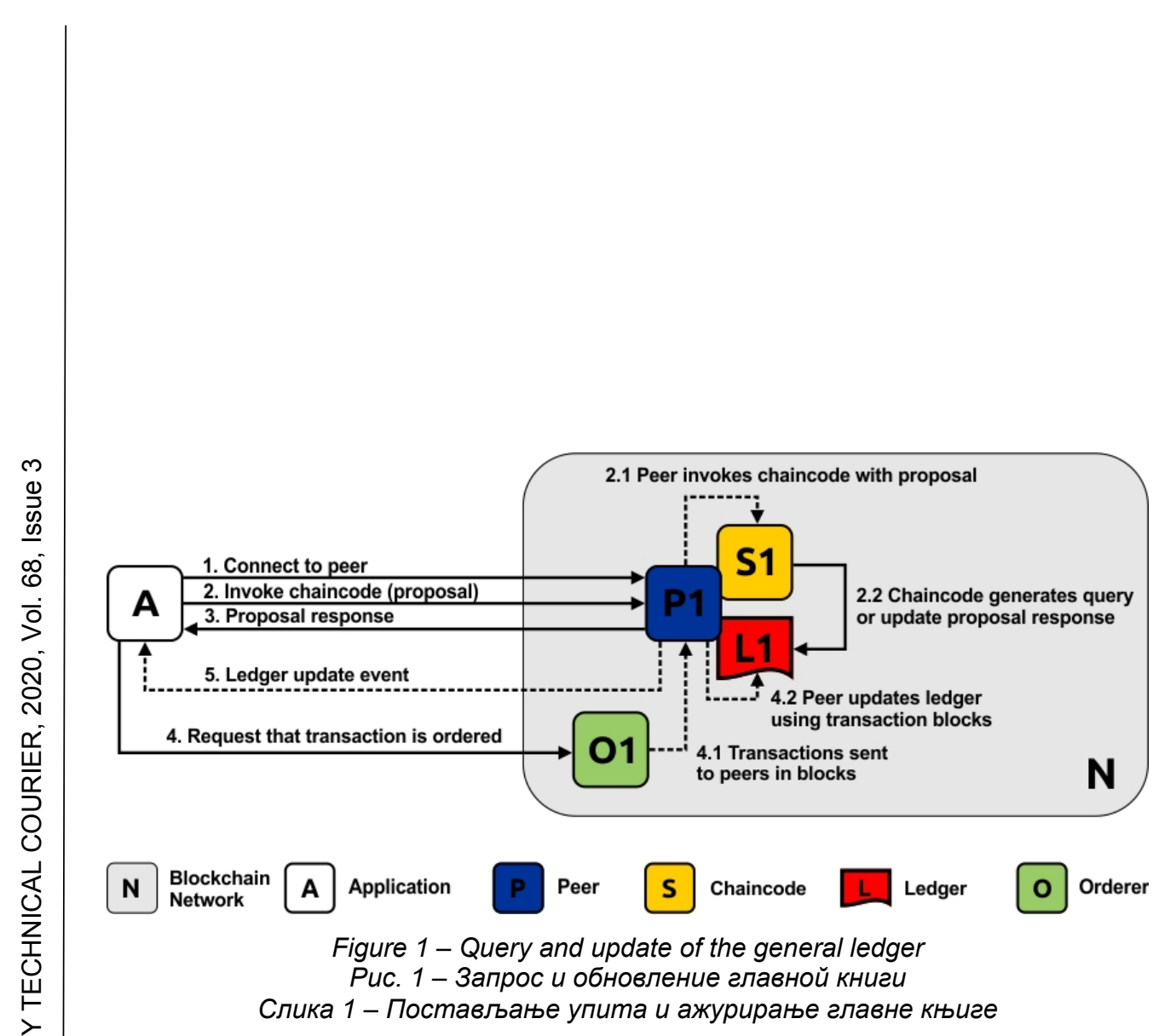

\section{Organizational focus}

Blockchain networks are managed by a set of organizations, not a single organization. Nodes are key to building this type of distributed network. They are the property of organizations and their network connection points. As a business-oriented system, Hyperledger Fabric distinguishes between peers, customers and the organization that owns them. It is intended to create networks between organizations, and the clients who run Blockchain do so as agents of that organization.

Each node on the network uses the Blockchain network on behalf of the participating organization. This is different from networks such as Ethereum and Bitcoin, where a network is created by a set of computers that independently contribute resources to the network, or the network perceives it to do so independently, regardless of who owns them. At Hyperledger Fabric, the organizations that create the general ledger are the ones that contribute to the network by contributing resources in the form of peers and clients. The difference is subtle but crucial. In most public networks, the idea is to allow computers to coordinate, but in Hyperledger Fabric, the idea is to allow companies to coordinate. Organizations give each of their peers a signed digital certificate proving their membership in a particular organization. This certificate then allows each subscriber to connect to the network through a membership service provider, giving them access to network resources. The focus on organizations versus the focus on private computers leads to another feature of Hyperledger Fabric that is focused on companies, and which is 
necessary due to a larger number of business requirements, i.e. private channels (Hill et al, 2018).

\section{Private channels}

There are different types of nodes with different roles in the network: endorser peer, anchor peer, and orderer peer. After receiving the request to call the transaction from the client application, the endorser peer confirms the transaction, which means checking the details of the certificate and the role of the applicant, and then executes the chain code and simulates the outcome of the transaction, but does not update the general ledger. The anchor peer receives updates and transmits updates to other nodes in the organization. The order peer is considered the central communication channel in the Hyperledger Fabric network. The order peer is responsible for the consistency of the general ledger status online. It creates blocks and delivers them to all nodes (Mamun, 2018).

A channel is a private "subnet" of communication between two or more specific network members to perform private and confidential transactions. The communication within the channel is isolated and protected, and transactions and data on the channel are visible only to channel members.

The channel is defined by members (organizations), anchor peers, general ledger, application chain(s), and ordering service. Every online transaction is executed on a channel, where each party must be verified and authorized to perform transactions on that channel. Each node that joins the channel has its own identity assigned to it by the membership service provider, which confirms the authenticity of each node to other nodes within the channel and services. Although nodes may belong to a number of channels, information on transactions, general ledger status, and channel membership is limited to nodes within each channel (Boaventura, 2018). If an organization has access to the Blockchain network, it has the ability to create and maintain a private channel with certain other members. Members (organizations) define and structure a channel to allow certain nodes to run private and confidential transactions, which other members of the same network cannot see and access. Each channel includes nodes, a common general ledger, chain codes on the channel, and one or more ordering services.

\section{Smart contracts}

In the Hyperledger Fabric network, smart contracts are also called the chaincode. Unlike Ethereum, the Hyperledger Fabric chain is not built 
directly into the general ledger itself. Instead, the chain code is installed on each node and interacts with the general ledger to read and update resource status information. Because the chaincode is signed and approved by all nodes, and because each node that uses part of the chaincode must acknowledge any change in the general ledger, this system still uses distributed contracts to allow a distributed and reliable consensus.

\section{Transaction flow}

In a distributed general ledger system, a consensus is the process of reaching agreement on the appropriate set of transactions to be added to the general ledger. In Hyperledger Fabric, the consensus involves three different steps (Kulkarni, 2019):

- transaction approval,

- ordering, and

- validation.

These steps ensure that network policies are followed. The implementation of these steps can be considered through the execution of the transaction flow. Otherwise, transactions must be executed, endorsed and then approved, because only such transactions can have an impact on the change of balance. The approval is guided by the policy according to which the participants approve the transaction. The endorsment policy defines which nodes must execute the transaction, and then agree on the results before recording the transaction. The ordering phase accepts the approved transactions and agrees to the request for the transaction to be recorded in the general ledger. Validation takes a block of transactions and confirms the accuracy of the results, including the approval check.

\section{Creating a Blockchain business network and cash} exchange application using the Hyperledger Fabric framework

The process of creating a Blockchain business network and a simple application for exchanging funds from one client's account to another's account, as well as the transaction process itself, will be presented in order to better understand the working principle of Hyperledger Fabric. In order to realize the above, the software for virtualization of operating systems, VirtualBox, was used, on which the Linux OS Ubuntu 18.04.2 LTS was installed and configured. The reason for choosing the 
mentioned operating system is the possibility of Hyperledger Fabric functioning only on Unix-based operating systems.

Installing the necessary prerequisites, local work environment and Hyperledger Fabric

Running the Hyperledger Composer and Hyperledger Fabric development tools requires certain prerequisites to be properly installed and configured. The prerequisites include:

- Docker Engine - basic client-server technology that builds and runs containers using Docker components and services;

- Docker Compose - a tool for initializing and running Docker applications consisting of multiple containers;

- Node - a platform, created using JavaScript, suitable for creating fast real-time applications;

- npm - an online repository of JavaScript modules, many of which are written specifically for Node;

- git - a free open source version control system designed to handle small or large projects with a focus on speed and efficiency;

- Python 2.7.x - interpreted, interactive, object-oriented high-level programming language.

Creating a local work environment requires the installation of the following tools:

- composer-cli - basic CLI tools for performing administrative, operational and development tasks;

- composer-rest-server - a utility for starting a REST server on a machine to represent a business network as a RESTful API;

- composer-playground - user interface for configuration, implementation and testing of business network;

- generator-hyperledger-composer - a tool for generating applications.

The Hyperledger Fabric installation procedure involves:

- creating and selecting a new directory;

- downloading and extracting downloaded tools needed to install Hyperledger Fabric;

- specifying the desired version of Hyperledger Fabric;

- launching Hyperledger Fabric;

- generating a PeerAdmin card (Figure 2). 
The PeerAdmin card is analogous to real business cards, and gives the cardholder the authority to deploy, delete, and manage business networks in a Hyperledger Fabric environment.

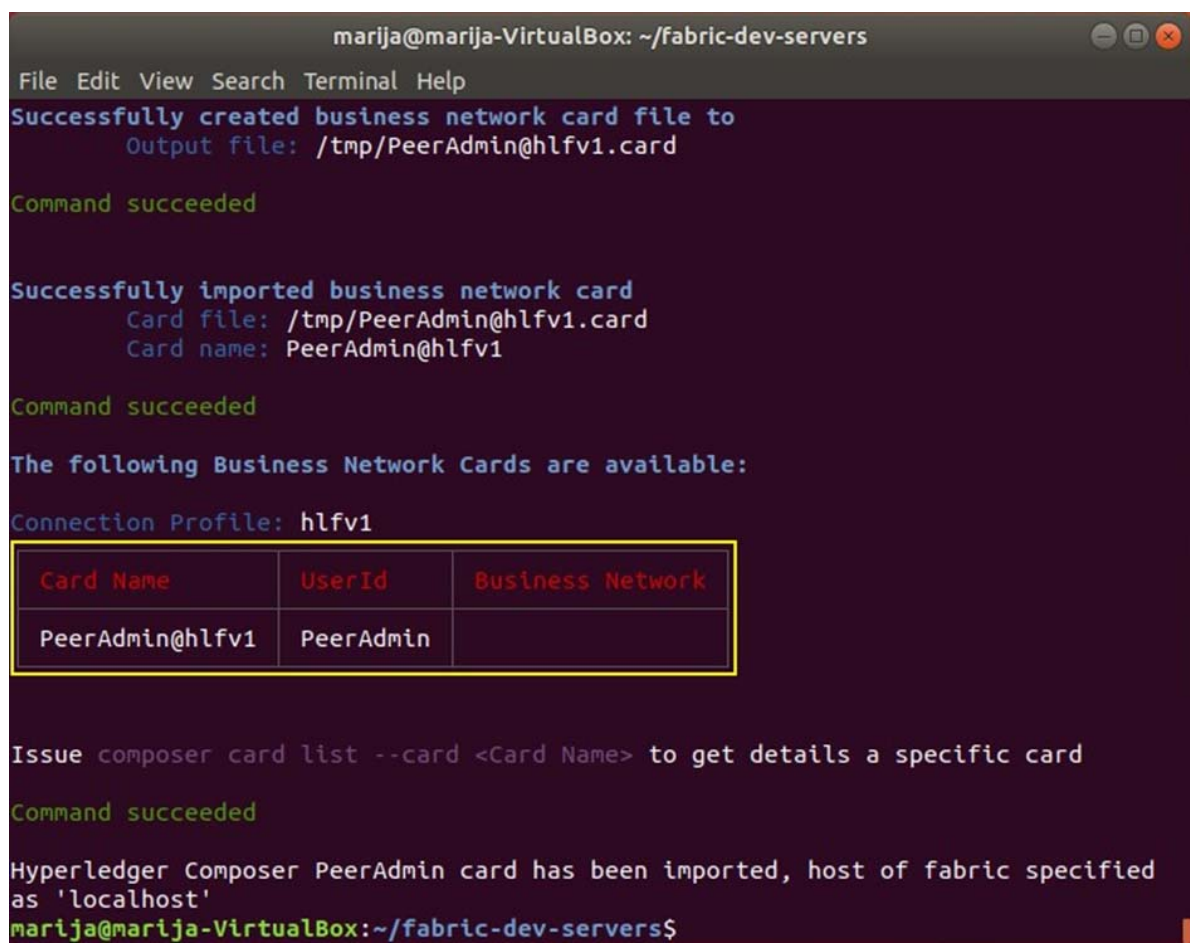

Figure 2 - Successfully generated PeerAdmin card

Puc. 2 - Успешно созданная карта PeerAdmin

Слика 2 - Успешно генерисана картица PeerAdmin

\section{Generating a business network}

After successful installation of the Hyperledger Fabric environment, it is necessary to generate a business network (Figure 3 ). The generated business network consists of data models, transaction logic and access control rules. The data model and access control rules are programmed in a domain-specific language, while the transaction logic is programmed in JavaScript. 
The Hyperledger composer generator, in addition to generating a business network, also enables generating application. Figure 4 shows a successfully generated application, while Figure 5 presents the balance on customer accounts after the transaction. 
File Edit View Search Terminal Help

harija@marija-VirtualBox: /fabric-dev-servers/prenos-novcanih-sredstava\$ yo hype

-ledger - composer

Welcome to the Hyperledger Composer project generator

Please select the type of project: Anqular

You can run this generator using: 'yo hyperledger-composer:angular'

elcome to the Hyperledger Composer Angular project generator

Do you want to connect to a running Business Network? Yes

Project name: aplikacija-za-prenos-novcanih-sredstava

Description: Aplikacija za brz i jednostavan prenos novcanih sredstava izmedju

racuna

Author name: Marija Krstic

Author email: krsticmarija1989@gmail.com

License: Apache-2.0

Name of the Business Network card: admin@prenos-novcanih-sredstava

Do you want to generate a new REST API or connect to an existing REST API? Co

Dect to an existing REST API

REST server address: http://localhost

REST server port: 3000

Should namespaces be used in the generated REST API? Namespaces are used

created application!

Figure 4 - Successfully generated application

Puc. 4 - Успешно созданное приложение

Слика 4 - Успешно генерисана апликација

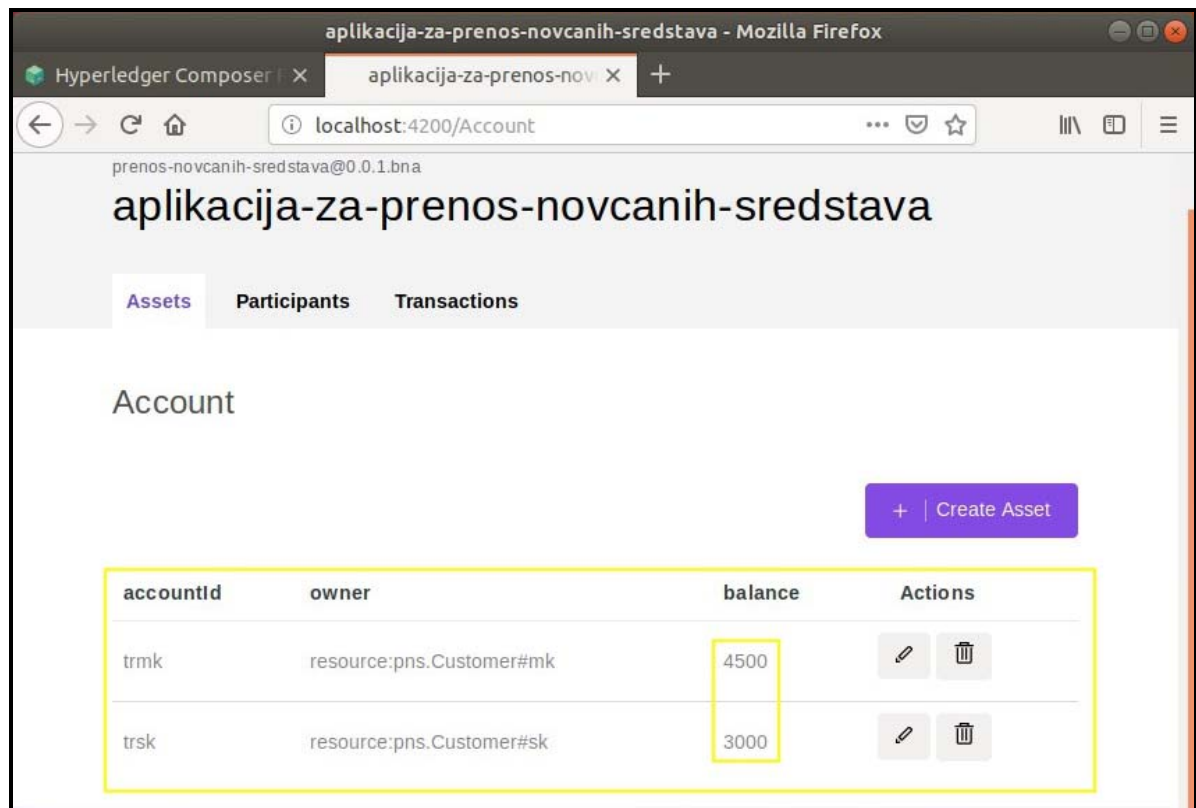

Figure 5 - Balance on the client accounts after a transaction

Puc. 5 - Сальдо по счетам клиентов после транзакции

Слика 5 - Салдо на рачунима клијената након трансакције 


\section{Conclusion}

Organizations whose business is based on the application of Blockchain technology have a bright future, and the reason lies in the fact that it is a promising new technology for secure online transactions. This technology creates the opportunity to establish accountability based on reliable real-time information exchange between organizations involved in a multi-party business structure. It can offer practical and efficient solutions that can be applied in the system creation, which can bring competitive advantages to organizations in technological and operational terms.

Blockchain technology is increasingly used in systems whose characteristics such as distribution, accessibility, security and trust are among the main qualities of the services and products they offer. In this regard, and in order to develop the best possible stand-alone or integrated Blockchain solutions, the Hyperledger project was created, within which numerous platforms and tools for the development of various Blockchain systems were developed. The Hyperledger family consists of six projects and a set of support tools, all with subtly different focuses and benefits to suit different needs. Hyperledger' $s$ main goal is to take business transactions to a whole new level that includes major global processes.

The most voluminous and flexible project, designed with the largest number of use cases, is Hyperledger Fabric. Responding to business needs, Hyperledger Fabric has evolved significantly in recent years and now accounts for most of the features that businesses can rely on.

Hyperledger Fabric is designed for corporate use from the start. It is the most active of all other Hyperledger projects, and the community gathered around the platform is constantly growing. As such, it has already been successfully implemented in many areas such as banking, finance, retail, and healthcare. This open-source Blockchain is supported by a consortium of large technology companies such as IBM, Cisco, SAP, Intel, and Oracle.

\section{References}

Belotti, M., Božić, N., Pujolle, G., \& Secci, S. 2019. A Vademecum on Blockchain Technologies: When, Which and How. IEEE Communications Surveys \& Tutorials, 21(4), pp.3796-3838. Available at: https://doi.org/10.1109/COMST.2019.2928178. 
-Blockstuffs. 2018. Introduction of Hyperledger, its projects and tools [online]. Available at: https://www.blockstuffs.com/blog/introduction-ofhyperledger-its-projects-and-tools [Accessed: 02 April 2020].

Boaventura, A. 2018. Getting to know Oracle Autonomous Blockchain Cloud Service - Part 1 -Working with Provisioning Interface [online]. Available at: https://medium.com/oracledevs/getting-to-know-oracle-autonomous-blockchaincloud-service-working-with-provisioning-interface-fb3be5179daf [Accessed: 05 April 2020].

Dhillon, V., Metcalf, D., \& Hooper, M. 2017. Blockchain Enabled Applications: Understand the Blockchain Ecosystem and How to Make it Work for You. New York, NY: Apress.

Gajić, D., 2018. Šta je Hyperledger i kako vam može pomoći u razvoju Blockchain aplikacija [online]. Available at: https://startit.rs/sta-je-hyperledger-ikako-vam-moze-pomoci-u-razvoju-Blockchain-aplikacija/ (in Serbian) [Accessed: 21 March 2020].

Hill, B., Chopra, S., \& Valencourt, P. 2018. Blockchain Quick Reference. Birmingham, UK: Packt Publishing.

-Hyperledger. 2018. Hyperledger Architecture, Volume II Smart Contracts. 2018. [online]. Available at: https://www.hyperledger.org/wpcontent/uploads/2018/04/Hyperledger_Arch_WG_Paper_2_SmartContracts.pdf [Accessed: 21 March 2020].

-Hyperledger. 2020a. Hyperledger Burrow [online]. Available at: https://www.hyperledger.org/projects/hyperledger-burrow [Accessed: 29 March 2020].

-Hyperledger. 2020b. Hyperledger Sawtooth [online]. Available at: https://www.hyperledger.org/projects/sawtooth [Accessed: 29 March 2020].

-Hyperledger. 2020c. Peers [online]. Available at: https://hyperledgerfabric.readthedocs.io/en/release-1.4/peers/peers.html [Accessed: 04 April 2020].

-Hyperledger. 2020d. Hyperledger Blockchain Technologies for Business [online]. Available at: https://www.hyperledger.org/wpcontent/uploads/2018/10/Hyperledger_DataSheet_10.18_Web-2.pdf [Accessed: 04 April 2020].

Hyperledger-fabricdocs Documentation. 2019. [e-book]. Hyperledger. Available at: https://buildmedia.readthedocs.org/media/pdf/hyperledgerfabric/release-1.2/hyperledger-fabric.pdf [Accessed: 04 April 2020].

-IBM Global Business Services. 2019. Blockchain: Emerging Use Cases for Insurance [online]. Available at: https://www.the-digital-insurer.com/wpcontent/uploads/2019/02/1409-Blockchain-Emerging-Use-Cases-forInsurance.pdf [Accessed: 29 March 2020].

Kuhrt, T. 2019. Hyperledger Caliper [online]. Available at: https://wiki.hyperledger.org/display/caliper/Hyperledger+Caliper [Accessed: 02 April 2020].

Kulkarni, S. 2019. Exploring Transaction Flow in Hyperledger Fabric [online]. Available at: https://opensourceforu.com/2019/01/exploring-transactionflow-in-hyperledger-fabric/ [Accessed: 07 April 2020]. 
Mamun, M. 2018. How does Hyperledger Fabric works [online]. Available at: https://medium.com/coinmonks/how-does-hyperledger-fabric-workscdb68e6066f5 [Accessed: 04 April 2020].

Minović, M. 2017. Blockchain technology: usage beside cripto currencies. In: Infotech 2017: ICT conference \& exhibition, Arandjelovac, Serbia, June 7-8. Available at: http://infotech.org.rs/pdf/011.pdf (in Serbian) [Accessed: 02 April 2020].

Nasir, Q., Qasse, I.A., Abu Talib, M., \& Nassif, A.B. 2018. Performance Analysis of Hyperledger Fabric. Security and Communication Networks Platforms, 2018, Article ID 3976093. Available at: https://doi.org/10.1155/2018/3976093.

Pavlović, R. 2018. New Tendencies of Blockchain Technology in Insurance with a Potential Greater Than Bitcoin Mining. In: SorS 2018: 29. susret osiguravača i reosiguravača, Sarajevo, B\&H, pp.239-255, June 6-8. Available at: https://brankopavlovic.rs/documentation/SORS2018.pdf (in Serbian) [Accessed: 02 April 2020].

Piljan, T., Piljan, I., \& Cogoljević, D. 2018. Uticaj Blockchain tehnologije na osiguranje. Vojno delo, 70(2), pp.360-373 (in Serbian). Available at: https://doi.org/10.5937/vojdelo1802360R.

Suprunov, P. 2018. 5 Hyperledger Projects In Depth [online]. Available at: https://medium.com/practical-blockchain/5-hyperledger-projects-in-depth3d14c41f902b [Accessed: 27 March 2020].

Verhoelen, J. 2018. An overview of Hyperledger blockchain projects [online]. Available at: https://blog.codecentric.de/en/2018/03/blockchain-projecthyperledger/ [Accessed: 30 March 2020].

ПРОГРАММНАЯ ПЛАТФОРМА HYPERLEDGER С ОСОБЫМ АКЦЕНТОМ НА БЛОК-СХЕМУ HYPERLEDGER FABRIC

Мария С. Крстич, корреспондент, Лазар Й. Крстич

Академия профессионального образования Южная Сербия,

Департамент бизнес-образования,

г. Лесковац, Республика Сербия

РУБРИКА ГРНТИ: 20.00.00 ИНФОРМАТИКА;

20.15.05 Информационные службы, сети, системы в целом

ВИД СТАТЬИ: профессиональная статья

Резюме:

Введение/цель: Развивающийся рынок блокчейнов с каждым днем становится все интереснее для многих отраслей, которые вследствие изменения условий ведения бизнеса, стали лучше понимать насколько важно иметь и пользоваться блокчейнами. 
После вступительного ознакомления с концепцией Blockchain в статье представлены проекты в рамках инициативы компании Linux Foundation, с особым акцентом на деятельность Hyperledger Fabric eе концепциях, архитектуре, организационной направленности, частных каналах и умных-контрактах, а также на потоке транзакций в сети Hyperledger Fabric. B последней практической части статьи представлены бизнес-симуляция и разработанное простое приложение для обмена денежных средств с помощью системы Hyperledger Fabric. Целью данной статьи является представление рабочих условий Hyperledger $и$ выявление всех деталей Hyperledger Fabric, для того чтобы можно было понять насколько применение системы Hyperledger на практике является обоснованным.

Методы: В работе применялись основные методы (анализ, синтез, дедукция, индукция, конкретизация, обобщение), а также общенаучные методы (аналитико-дедуктивный и сравнительный). Результаты: Были рассмотрены все релевантные характеристики Hyperledger Fabric, создана бизнес-сеть блокчейнов и разработано приложение для обмена денежных средств в сети.

Выводы: Hyperledger Fabric - это самая масштабная и гибкая Hyperledger программная платформа с наибольшим количеством пользователей.

Ключевые слова: Blockchain, Hyperledger, Hyperledger Fabric.

\section{РАДНА ОКРУЖЕЊА НYPERLEDGER СА ПОСЕБНИМ ОСВРТОМ HA HYPERLEDGER FABRIC}

Марија С. Крстић, аутор за преписку, Лазар Ј. Крстић

Академија струковних студија Јужна Србија, Одсек за пословне студије,

Лесковац, Република Србија

ОБЛАСТ: информационе технологије

ВРСТА ЧЛАНКА: стручни рад

\section{Сажетак:}

Увод/циљ: Мада je Blockchain тржиште у развоју, многе индустрије, услед променљивих услова пословања, све више разумеју важност његовог постојања и примене. Након уводног разматрања појма Blockchain-a, истраживање се наставља у правцу упознавања са пројектима у оквиру иницијативе Hyperledger фоноације Linux, са посебним освртом на Hyperledger Fabric, гde ће бити речи о концептима, архитектури, организационом фокусу, приватним каналима и паметним 
уговорима, као и току трансакција у мрежи Hyperledger Fabric. $\mathrm{y}$ последњем практичном делу рада приказана је симулација пословне мреже и креиране су једноставне апликације за размену новчаних средстава применом радног окружења Hyperledger Fabric. Циљ рада јесте упознавање са радним окружењима Hyperledger u истицање свих појединости Hyperledger Fabric-a ради утврђивања оправданости његове примене у пракси.

Методе: Коришћене су основне методе (анализа, синтеза, дедукција, индукција, конкретизација, генерализација), као и опите научне методе (аналитичко-дедуктивна и компаративна).

Резултати: Сагледане су релевантне карактеристике Hyperledger Fabric-a, његовом применом изграђена пословна мрежа Blockchain и креирана апликација за размену новчаних средстава посредством изграђене мреже.

Закључак: Hyperledger Fabric представља најобимније $u$ најфрлексибилније радно окружење Hyperledger са највећим бројем случајева употребе.

Кључне речи: Blockchain, Hyperledger, Hyperledger Fabric.

Paper received on / Дата получения работы / Датум пријема чланка: 28.04.2020. Manuscript corrections submitted on / Дата получения исправленной версии работы / Датум достављања исправки рукописа: 22.05.2020.

Paper accepted for publishing on / Дата окончательного согласования работы / Датум коначног прихватања чланка за објављивање: 24.05.2020.

( 2020 The Authors. Published by Vojnotehnički glasnik / Military Technical Courier (www.vtg.mod.gov.rs, втг.мо.упр.срб). This article is an open access article distributed under the terms and conditions of the Creative Commons Attribution license (http://creativecommons.org/licenses/by/3.0/rs/).

(c) 2020 Авторы. Опубликовано в «Военно-технический вестник / Vojnotehnički glasnik / Military Technical Courier» (www.vtg.mod.gov.rs, втг.мо.упр.срб). Данная статья в открытом доступе и распространяется в соответствии с лицензией «Creative Commons» (http://creativecommons.org/licenses/by/3.0/rs/).

(c) 2020 Аутори. Објавио Војнотехнички гласник / Vojnotehnički glasnik / Military Technical Courier (www.vtg.mod.gov.rs, втг.мо.упр.срб). Ово је чланак отвореног приступа и дистрибуира се у складу са Creative Commons licencom (http://creativecommons.org/licenses/by/3.0/rs/).

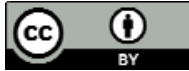

